Research Article

\title{
Development and Validation of a Stability-indicating Method for the Determination of Pazopanib Hydrochloride by RP-HPLC
}

\author{
P. Ravisankar*, M. Nithya Satya, K. Saisneha lata, A. Bhavani Sailu, Sk. Rijwana, K. Harsha Sri, K. Pujitha \\ Department of Pharmaceutical Analysis, Vignan Pharmacy College, Vadlamudi, Guntur-522 213, Andhra Pradesh, India. \\ *Corresponding author's E-mail: banuman35@gmail.com
}

Received: 06-03-2021; Revised: 25-04-2021; Accepted: 30-04-2021; Published on: 15-05-2021.

\begin{abstract}
A precise, accurate, highly sensitive, rapid, and reproducible stability HPLC method was developed and validated for the estimation of Pazopanib Hydrochloride (PAZO) in bulk and tablet dosage form. Decent quality chromatographic separation of Pazopanib Hydrochloride was done by using Eclipse plus $\mathrm{C}_{18}$ column $(4.5 \mathrm{~mm}$ i.e. X $150 \mathrm{~mm}$, 3.5 $\mathrm{m}$ particle size) (based on $99.99 \%$ ultra-high purity silica) using mobile phase that containing $0.1 \%$ Orthophosphoric acid: Acetonitrile $(55: 45 \% \mathrm{v} \backslash \mathrm{v})$ at a flow rate of $1.0 \mathrm{~mL} / \mathrm{minute}$. The wavelength $\lambda_{\max }$ of PAZO used for the detection was found to be $271.4 \mathrm{~nm}$. The retention time for Pazopanib was found to1.43 minutes. The PAZO was linear in the concentration range of $2-10 \mu \mathrm{g} / \mathrm{mL}\left(\mathrm{r}^{2}=0.9999\right)$ for HPLC method. The regression equation for PAZO was found to be $Y=700955 x+28022$ for HPLC. The LOD and LOQ were found to be $0.1675 \mu \mathrm{g} / \mathrm{mL}, 0.0552 \mu \mathrm{g} / \mathrm{mL}$ for the HPLC method, respectively. The developed methods are validated in pursuance of ICH Q2 (R1) guidelines. The method was linear, precise, accurate with recoveries in the range of $98-102 \%$, and minimum values of $\%$ RSD indicate the accuracy of the method. The \% assay of the PAZO was found to be $99.85 \pm 1.2$, which was in good agreement with the labeled claim. Pazopanib was subjected to stressed conditions like acidic, basic, oxidative, photolytic, and thermal conditions. The degradation results were found satisfactory. The developed gradient RP-HPLC method can be successfully practiced for the routine quality control analysis of PAZO in pharmaceutical tablets and routine quality control analysis.
\end{abstract}

Keywords: Pazopanib Hydrochloride, forced degradation, RP-HPLC, Method validation.

QUICK RESPONSE CODE $\rightarrow$

DOI:

10.47583/ijpsrr.2021.v68i01.035

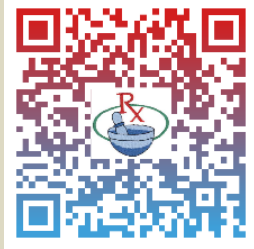

DOI link: $\underline{\text { http://dx.doi.org/10.47583/ijpsrr.2021.v68i01.035 }}$

\section{INTRODUCTION}

T he chemical name for PAZO Fig. 1, 5-[[4-[(2, 3dimethylindazol-6-yl)-methyl amino] pyrimidin-2-yl] amino]-2-methylbenzenesulfonamide. It has the molecular formula $\mathrm{C}_{21} \mathrm{H}_{23} \mathrm{~N}_{7} \mathrm{O}_{2} \mathrm{~S} . \mathrm{HCl}$ and a molecular weight of 473.991 PAZO are used to treat advanced Kidney cell Carcinoma and it is also used to treat advanced soft tissue and it is also potent a selective multi-targeted receptor tyrosine kinase inhibitor that blocks tumor growth and inhibits angiogenesis.

As per the Literature Survey, it is revealed that the drug has been estimated by LC-MS/MS ${ }^{1-5}$, UPLCQ-TOF/MS ${ }^{6}$, High-Performance Liquid Chromatography -UV ${ }^{7-11}$, Ultra Violet ${ }^{12-13}$ But only a few stability-indicating methods for the determination of PAZO HPLC analysis has been reported for the estimation in pharmaceutical dosage forms. Mostly, HPLC has proven to be valuable in diagnostic purposes and the pharmaceutical industry ${ }^{14-16}$.<smiles>Cc1ccc(Nc2nccc(N(C)C3=CCc4c(nn(C)c4C)C3)n2)cc1S(N)(=O)=O</smiles>

Figure 1: Chemical Structure of Pazopanib hydrochloride

\section{MATERIALS AND METHODS}

\section{Chemicals and Reagents}

A sample of PAZO was gifted from Hetero Labs Ltd., Hyderabad, India PAZO (Pazopanib Hydrochloride 200 mg.) was purchased from a local pharmacy. HPLC grade Methanol, HPLC grade Acetonitrile, High purity water was prepared using Milli $Q$ purification system from Millipore, Bangalore, India, and AR grade Sodium Hydroxide, AR grade Hydrogen Peroxide were purchased from Merck specialties Pvt. Ltd., Mumbai, India.

\section{Instrumentation}

For UV detection of the sample, an ELICO SL-210 UV spectrophotometer with $1 \mathrm{~cm}$ matched quartz cells were used for all spectral and absorbance measurements, and solutions were prepared in methanol. For HPLC, the chromatographic system consists of Agilent HPLC quaternary-1260 Infinite- II 
series, Eclipse plus $\mathrm{C}_{18}$ column, 1260 series with diode array detector was used for higher data quality for more confidence. For homogenizing the solution prepared, Ultra-Sonicator of Spectral labs, model UCB 40 was used. For weighing of the sample and excipients, Radwag analytical balance AS 82/220.R2) (0.01g), was used. For measuring the $\mathrm{pH}$ of the prepared solutions $\mathrm{pH}$ meter, the Systronics model - 802 was used. The data was acquired and processed by utilizing EZ chrome elite software.

\section{Method development and optimization of chromatographic conditions}

For HPLC development, a variety of mobile phases containing HPLC grade water, acetonitrile, methanol in different ratios with or without buffers, and also various flow rates were performed. A good symmetrical peak was found when the mobile phase containing a mixture of $0.1 \%$ Orthophosphoric acid: Acetonitrile (55:45\% $v \backslash v)$

\section{Selection of detection wavelength}

To estimate the maximum $\lambda_{\max }$, PAZO $100 \mu \mathrm{g} / \mathrm{ml}$ of working standard solution was prepared and scanned in a UV wavelength range of $200-400 \mathrm{~nm}$ utilizing as a blank. It was observed that the drug showed maximum absorbance at $273 \mathrm{~nm}$ in methanol. $0.1 \%$ Orthophosphoric acid: acetonitrile in the ratio of 55:45 $v / v$, in which the detection wavelength was found to be 271.4, so for HPLC this wavelength was chosen as the detection wavelength for the determination of PAZO. As a matter of fact, in this wavelength exquisite symmetric peak is obtained. The overlay spectrum of PAZO is shown in Fig. 1a.

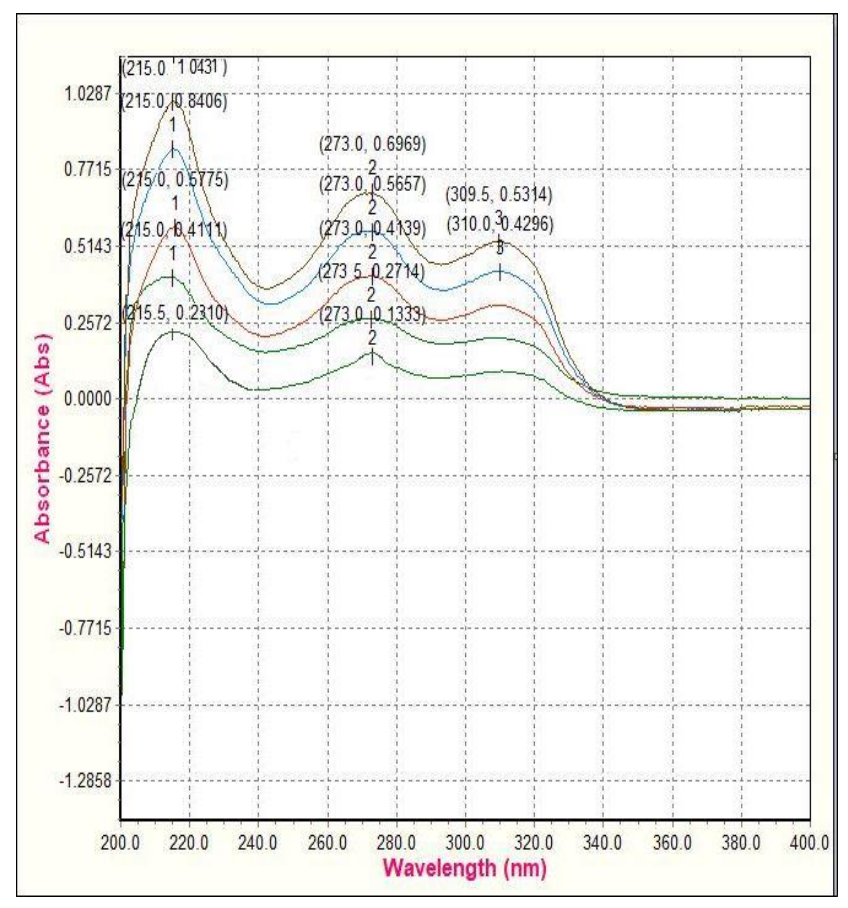

Figure 1a: Overlay Spectrum of Pazopanib Hydrochloride for UV method

\section{Preparation of the mobile phase}

The mobile phase was prepared by mixing $0.1 \%$ Orthophosphoric acid and acetonitrile in the proportion of 55: $45 \mathrm{v} / \mathrm{v}$. The prepared mobile phase was filtered through a $0.45 \mu \mathrm{m}$ nylon membrane filter and degassed by sonication.

\section{Preparation of Stock and Working standard solution}

Precisely weighted $100 \mathrm{mg}$ of PAZO was transferred into $100 \mathrm{~mL}$ volumetric flask, dissolved, and diluted up to the mark with mobile phase to get a stock solution containing $1.0 \mathrm{mg} / \mathrm{mL}$ of PAZO. Aliquots of stock solution were diluted with mobile phase to attain the calibration standard solutions over the range of $2,4,6,8$, and $10 \mu \mathrm{g} / \mathrm{mL}$.

\section{Preparation of sample solution}

For the assay of pharmaceutical formulation, 20 tablets of PAZO marketed formulation (Votrient $200 \mathrm{mg}$ ) were weighed, the average weight was calculated, and a quantity of tablet powder equivalent to $100 \mathrm{mg}$ of PAZO was accurately weighed and transferred into a $100 \mathrm{~mL}$ volumetric flask containing $30 \mathrm{~mL}$ of the mobile phase. The solution was ultra-sonicated for about 15 minutes, filtered through a What man filter paper $(0.45 \mu \mathrm{m})$ nylon filter and the filtrate was made up to volume with the mobile phase. The concentration was $1 \mathrm{mg} / \mathrm{mL}$. Transfer $1 \mathrm{ml}$ of the filtered sample solution to $10 \mathrm{~mL}$ volumetric flask and made up to volume with mobile phase to get a solution of $100 \mu \mathrm{g} / \mathrm{mL}$. The solution is further diluted with mobile phase to obtained the required concentrations. This is used as a working solution for the preparation of the assay. Then $0.2 \mathrm{ml}$ of this solution is transferred into a $10 \mathrm{ml}$ volumetric flask and made up to volume to obtain $2 \mu \mathrm{g} / \mathrm{mL}$ which is used for the assay. The assay results are presented in Table 4. Representative in Assay results of PAZO by HPLC. Solutions were injected as per the above chromatographic conditions and peak areas were recorded. The quantifications were carried out by keeping these values to the straight-line equation of the calibration curve.

\section{Method development optimization}

The optimized HPLC conditions of several mobile phases with different compositions were tested to develop an optimization of chromatographic conditions like tailing factor, peak shape, and the number of theoretical plates. For the selection of the mobile phase, primarily methanol: acetonitrile, ethanol: water, acetonitrile: water has been tested for different compositions. Eventually, the gradient mode and mobile phase containing a mixture of $0.1 \%$ Orthophosphoric acid: Acetonitrile (55:45\% vlv) at a flow rate of $1 \mathrm{~mL} /$ minute was found to be satisfactory and proper system suitability parameters obtained. Optimized chromatographic conditions, system suitability parameters for estimation of PAZO by proposed gradient RP-HPLC method are depicted in Table 1. 
Table 1: Optimized chromatographic conditions for the proposed HPLC method

\begin{tabular}{|c|c|}
\hline Parameter & Chromatographic conditions \\
\hline Instrument & $\begin{array}{l}\text { Agilent HPLC quaternary-1260 } \\
\text { Infinite- II series }\end{array}$ \\
\hline Column & $\begin{array}{l}\text { Eclipse plus } \mathrm{C}_{18} \text { column ( } 4.5 \mathrm{~mm} \text { i.d. } \\
\mathrm{X} 150 \mathrm{~mm}, 3.5 \mu \mathrm{m} \text { particle size) } \\
\text { (based on } 99.999 \% \text { ultra-high purity } \\
\text { silica) }\end{array}$ \\
\hline Detector & 1260 Diode Array Detector. \\
\hline Mobile phase & $\begin{array}{l}0.1 \quad \% \\
\text { Orthophosphoricacid:Acetonitrile } \\
(55: 45 \% v \backslash v) .\end{array}$ \\
\hline Flow rate & $1 \mathrm{~mL} / \mathrm{minute}$ \\
\hline $\begin{array}{l}\text { Detection } \\
\text { wavelength }\end{array}$ & $\begin{array}{l}\text { In methanol, the wavelength was } \\
273 \mathrm{~nm} \text {, in HPLC mobile phase } 271.4 \\
\mathrm{~nm} \text {. }\end{array}$ \\
\hline Run time & 5 minutes \\
\hline Temperature & Room temperature $\left(25^{\circ} \mathrm{C}\right)$. \\
\hline $\begin{array}{l}\text { The volume of } \\
\text { injection loop }\end{array}$ & $10 \mu \mathrm{L}$ \\
\hline Retention time $\left(R_{t}\right)$ & 1.403 minutes \\
\hline $\begin{array}{l}\text { Theoretical plates } \\
\text { [th.pl] (Efficiency) }\end{array}$ & 3863 \\
\hline $\begin{array}{l}\text { Theoretical plates } \\
\text { per meter }[\text { t.p/m] }\end{array}$ & 77360 \\
\hline $\begin{array}{l}\text { Tailing factor } \\
\text { (asymmetry) }\end{array}$ & 1.12 \\
\hline
\end{tabular}

\section{Method Validation ${ }^{17-20}$}

Validation is a process of establishing documented evidence, which provides a high degree of assurance that a specific activity will consistently produce a desired result or product meeting its pre-determined specifications and quality characteristics. The method was validated as per $\mathrm{ICH}$ guidelines.

\section{System suitability}

System suitability parameters can be defined as tests to ensure that the method can generate results of acceptable accuracy and precision. The requirements for system suitability are usually developed after method development and validation have been completed. The system suitability parameters like theoretical plates, retention time, tailing factor, were studied and found satisfactory. The results show the system suitability parameters in Table 1 a.
Table 1a: System suitability parameters

\begin{tabular}{|l|l|l|}
\hline $\begin{array}{c}\text { System Suitability } \\
\text { parameters }\end{array}$ & Limits & $\begin{array}{l}\text { Pazopanib } \\
\text { Hydrochloride }\end{array}$ \\
\hline Tailing factor (T) & $\leq 2.0$ & 1.12 \\
\hline $\begin{array}{l}\text { Number of theoretical } \\
\text { plates }\end{array}$ & NLT 2000 & 3863 \\
\hline $\begin{array}{l}\text { Theoretical plates per } \\
\text { meter (N) }\end{array}$ & - & 77,360 \\
\hline $\begin{array}{l}\text { Retention time* } \\
\text { SD for peak area for RT }\end{array}$ & - & 1.430 minutes \\
\hline \% RSD & NMT 2.0 & 0.112 \\
\hline
\end{tabular}

* Average of five determinations, SD = Standard deviation, $\mathrm{RSD}=$ relative standard deviation .

The result is well within the acceptance criteria, and the study concludes the suitability of the analytical system for the analysis.

\section{Precision}

\section{System precision}

For RP-HPLC, six replicate injections of standard $10 \mu \mathrm{g} / \mathrm{mL}$ and blank were injected into the HPLC system. The system precision responses are represented in table 2.

Table 2: System Precision

\begin{tabular}{|l|c|}
\hline Injection No. & Area Response \\
\hline 1 & 6978057 \\
\hline 2 & 6979165 \\
\hline 3 & 6978054 \\
\hline 4 & 6977163 \\
\hline 5 & 6978274 \\
\hline 6 & 6979385 \\
\hline Mean & 6978350 \\
\hline RSD & 0.011683 \\
\hline
\end{tabular}

\section{Method precision \& intermediate precision}

For method precision, six test preparations were analyzed as per the methodology representing a single batch, and the assay was determined for the same. The \% RSD for assay of six test preparations should not be more than 2.0. The results are well within acceptance criteria, and the \% RSD observed for assay values indicates the precision of the method.

For intermediate precision, six sample preparations were made and analyzed as per the method by different analysts using various instruments and different columns on different days. The \% RSD values for assay of 6 test preparations should not be more than 2.0. Cumulative \% RSD of 12 determinations, ie., method and intermediate precision should not be more than 2.0. The results are well within acceptance criteria, and the \% RSD observed for 
assay indicates the precision of the method. The resultant values for method precision \& Intermediate precision are depicted in Table2a.

Table 2a: Complied data of method precision \& intermediate precision

\begin{tabular}{|l|c|c|}
\hline Injection No. & $\begin{array}{c}\text { Method } \\
\text { Precision }\end{array}$ & $\begin{array}{c}\text { Intermediate } \\
\text { Precision }\end{array}$ \\
\hline 1 & 98.2 & 99.2 \\
\hline 2 & 99.5 & 99.5 \\
\hline 3 & 98.3 & 98.1 \\
\hline 4 & 99.3 & 98.4 \\
\hline 5 & 99.0 & 99.3 \\
\hline 6 & 98.6 & 99.5 \\
\hline Mean & 98.81667 & 99.00 \\
\hline \% RSD & 0.54087 & 0.60 \\
\hline Cumulative & RSD & 1.1205 \\
\hline
\end{tabular}

\section{Precision at different levels}

Precision at different levels of the analytical method was determined in the concentration range of $50 \%, 100 \%$, $150 \%$, their values are portrayed in Table $2 b$.

Table 2b: Precision at $50 \%, 100 \%, 150 \%$ (Precision at different levels)

\begin{tabular}{|l|c|c|c|}
\hline S. No. & $\mathbf{5 0} \%$ & $\mathbf{1 0 0} \%$ & $\mathbf{1 5 0} \%$ \\
\hline 1 & 1405868 & 2895311 & 427689 \\
\hline 2 & 1407879 & 2874522 & 428864 \\
\hline 3 & 1416558 & 2881294 & 428513 \\
\hline 4 & 1405689 & 2887523 & 428567 \\
\hline 5 & 1404567 & 2891485 & 427614 \\
\hline 6 & 1406776 & 2886454 & 428954 \\
\hline Mean & 1407890 & 2886098 & 428366.8 \\
\hline \% RSD & 0.31179 & 0.25609 & 0.13530 \\
\hline
\end{tabular}

\section{Linearity}

The linearity of PAZO was determined in the concentration range of 2 to $10 \mu \mathrm{g} / \mathrm{mL}$. The calibration graph of PAZO is shown in Fig. 2. The linearity data is presented in Table 2c, and the summary output of ANOVA study of PAZO is presented in Fig. 2a.

Table 2c: Linearity data of Pazopanib Hydrochloride by HPLC

\begin{tabular}{|l|l|l|}
\hline S. No. & Concentration & Area \\
\hline 1. & 0 & 0 \\
\hline 2. & 2 & 1405868 \\
\hline 3. & 4 & 2895311 \\
\hline 4. & 6 & 4231585 \\
\hline $\mathbf{5 .}$ & 8 & 5685969 \\
\hline 6. & 10 & 6978057 \\
\hline 7. & Intercept & 28022 \\
\hline 8. & Slope & 70095 \\
\hline
\end{tabular}

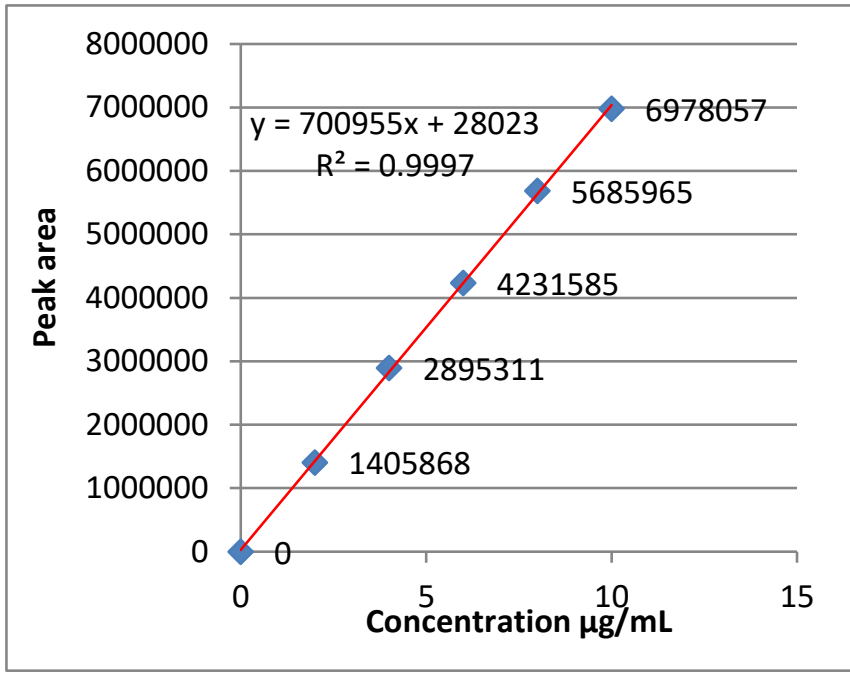

Figure 2: Calibration graph of Pazopanib Hydrochloride by RP- HPLC

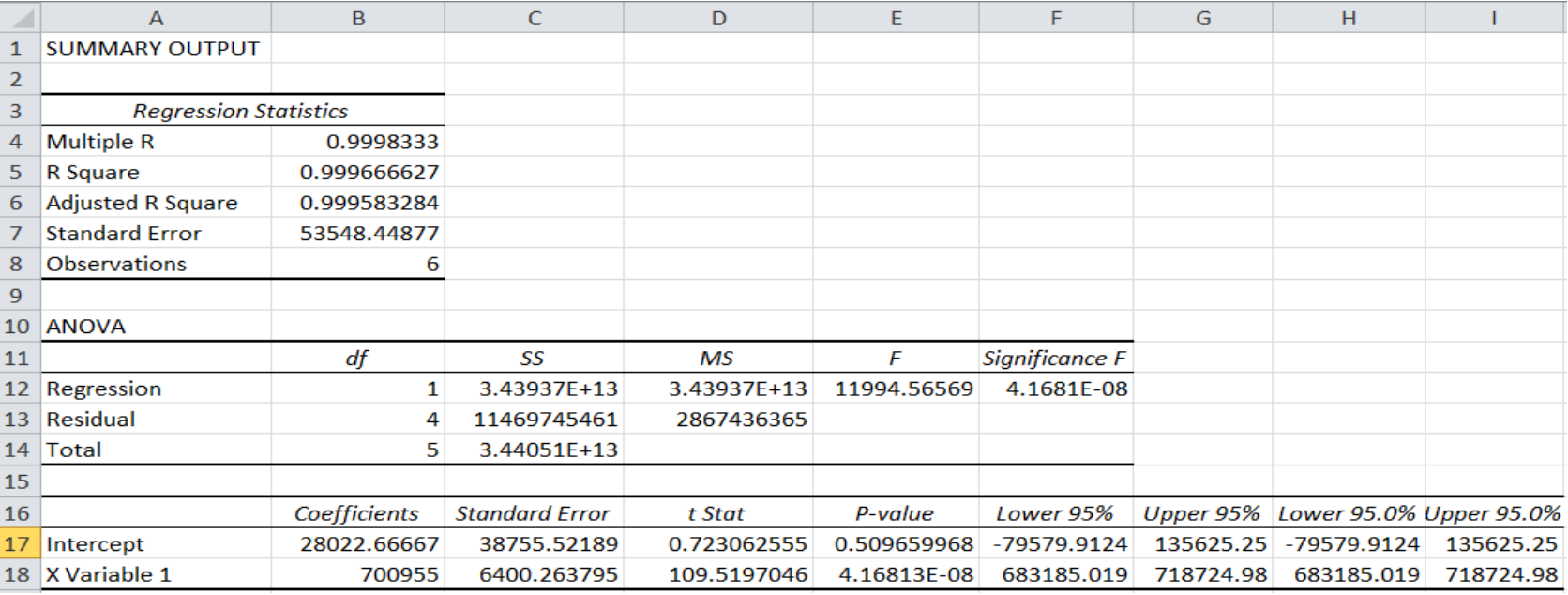

Figure 2a: The summary output of ANOVA study of Pazopanib Hydrochloride 


\section{Accuracy (Recovery studies)}

A known amount of drug was spiked with placebo at three different levels in triplicate preparations. The samples were then analyzed as per the proposed standard method. The accuracy studies of PAZO are mentioned in Table $2 \mathrm{~d}$.

\section{Robustness}

The robustness of the method was determined for the system suitability and assay value under variable conditions. The robustness of the analytical method was established by demonstrating its reliability against deliberate changes in the chromatographic conditions. The robustness of the method of PAZO is mentioned in Table 3.

Table 2d: Accuracy study of Pazopanib Hydrochloride

\begin{tabular}{|l|c|c|c|c|}
\hline $\begin{array}{l}\text { \% } \\
\text { Recovery }\end{array}$ & Level & $\begin{array}{c}\text { Amount } \\
\text { Added } \\
\text { (mg) }\end{array}$ & $\begin{array}{c}\text { Amount } \\
\text { recovered } \\
\mathbf{( m g )}\end{array}$ & $\begin{array}{c}\text { \% } \\
\text { Recovery }\end{array}$ \\
\hline $50 \%$ & 1 & 12.13 & 12.08 & 99.4 \\
\hline & 2 & 12.19 & 12.10 & 99.1 \\
\hline $100 \%$ & 3 & 12.07 & 11.95 & 99.5 \\
\hline & 1 & 24.50 & 24.10 & 98.1 \\
\hline & 2 & 24.63 & 24.48 & 99.2 \\
\hline & 3 & 24.70 & 24.51 & 99.6 \\
\hline & 1 & 36.90 & 36.76 & 99.7 \\
\hline & 2 & 37.01 & 36.80 & 99.7 \\
\hline & 3 & 36.79 & 36.71 & 99.4 \\
\hline
\end{tabular}

\section{$\angle O D$ and $L O Q$}

Limit of Detection is the lowest concentration in a sample that can be detected but not necessarily quantified under the stated experimental conditions. The limit of Quantitation is the lowest concentration of analyte in a sample that can be determined with acceptable precision and accuracy. The LOD and LOQ are shown in Table $3 a$.

Table 3a: LOD and LOQ results of Pazopanib Hydrochloride by HPLC

\begin{tabular}{|l|l|}
\hline Limit of Detection (LOD) & $0.1675 \mu \mathrm{g} / \mathrm{mL}$ \\
\hline Limit of Quantitation (LOQ) & $0.0552 \mu \mathrm{g} / \mathrm{mL}$
\end{tabular}

\section{Forced degradation studies:}

Forced degradation studies such as acid, base, peroxidase, dry heat, UV light have been carried to establish specificity and stability-indicating the nature of the method. The studies found that there is not much degradation occurs during the acid, base, peroxidase degradations. In fact, there are no co-eluting peaks with the Pazopanib. Peak purity of PAZO was found to be less than the purity threshold. Results of the forced degradation studies have been tabulated in Table $3 \mathrm{~b}$.

\section{Analysis of Pazopanib Hydrochloride in tablet formulation}

The developed and validated method was successfully applied for the determination of PAZO in their tablet dosage form. The assay result Table 4 shows that the amount of the drug was in excellent agreement with the labeled value of the formulation. The representative sample chromatogram of PAZO is shown in Fig. 4.

Table 3: Robustness results of Pazopanib Hydrochloride.

\begin{tabular}{|c|c|c|c|c|c|c|}
\hline Parameters & Optimized & Used & $\begin{array}{l}\text { Retention } \\
\text { time (min) }\end{array}$ & $\begin{array}{l}\text { Plate } \\
\text { count \$ }\end{array}$ & $\begin{array}{c}\text { Peak } \\
\text { asymmetry \# }\end{array}$ & Remarks \\
\hline \multirow{3}{*}{ Flow rate $\quad( \pm 0.2 \mathrm{~mL} / \mathrm{min})$} & \multirow{3}{*}{$1.0 \mathrm{~mL} / \mathrm{min}$} & $0.8 \mathrm{~mL} / \mathrm{min}$ & $1.51 \mathrm{~min}$ & 4756 & 1.249 & ${ }^{*}$ Robust \\
\hline & & $1.0 \mathrm{~mL} / \mathrm{min}$ & $1.40 \mathrm{~min}$ & 3848 & 1.127 & *Robust \\
\hline & & $1.2 \mathrm{~mL} / \mathrm{min}$ & $1.25 \mathrm{~min}$ & 2736 & 1.016 & *Robust \\
\hline \multirow{3}{*}{$\begin{array}{l}\text { Detection wavelength } \\
( \pm 5 \mathrm{~nm})\end{array}$} & \multirow{3}{*}{$271 \mathrm{~nm}$} & $260 \mathrm{~nm}$ & $1.40 \mathrm{~min}$ & 3847 & 1.249 & ${ }^{*}$ Robust \\
\hline & & $271 \mathrm{~nm}$ & $1.43 \mathrm{~min}$ & 3848 & 1.127 & *Robust \\
\hline & & $270 \mathrm{~nm}$ & $1.40 \mathrm{~min}$ & 3846 & 1.016 & ${ }^{*}$ Robust \\
\hline \multirow{2}{*}{$\begin{array}{l}\text { Mobile phase composition } \\
0.1 \% \\
\text { orthophosphoricacid:CAN } \\
(55: 45 \% \mathrm{v} / \mathrm{v})\end{array}$} & \multirow{2}{*}{$55: 45 \mathrm{v} / \mathrm{v}$} & $55: 45 \mathrm{v} / \mathrm{v}$ & $1.40 \mathrm{~min}$ & 3848 & 1.127 & *Robust \\
\hline & & $50: 50 \mathrm{v} / \mathrm{v}$ & $1.40 \mathrm{~min}$ & 3847 & 1.016 & *Robust \\
\hline
\end{tabular}

Acceptance criteria (Limits): "Peak Asymmetry <1.5, \$Plate count $>2000, *$ Significant change in Retention time.

Table 3b: Forced degradation studies

\begin{tabular}{|l|l|c|c|c|}
\hline S.No & Stress conditions & \% Assay & Peak Purity Angle & Peak purity threshold \\
\hline 1 & $2 \mathrm{~N} \mathrm{HCl}$ for 30 minutes at $60^{\circ} \mathrm{C}$ & 95.20 & 0.157 & 0.261 \\
\hline 2 & $2 \mathrm{~N} \mathrm{NaOH}$ for 30 minutes at $60^{\circ} \mathrm{C}$ & 97.12 & 0.222 & 0.264 \\
\hline 3 & $20 \% \mathrm{H}_{2} \mathrm{O}_{2}$ for 30 minutes at $60^{\circ} \mathrm{C}$ & 93.90 & 0.212 & 0.266 \\
\hline 4 & Dry heat $105^{\circ} \mathrm{C}$ for 6 hrs & 98.64 & 0.058 & 0.262 \\
\hline 5 & UV light 200 wts $/$ hr or 7 days & 99.04 & 0.067 & 0.326 \\
\hline
\end{tabular}


Table 4: Assay results of Pazopanib Hydrochloride by HPLC

\begin{tabular}{|l|l|l|l|l|l|l|}
\hline S. No. & Formulation & Labeled claim & Amount found* & Mean \% recovery \pm SD & \% RSD \\
\hline 1 & $\begin{array}{l}\text { Pazopanib Hydrochloride } \\
\text { tablets (Votrient) }\end{array}$ & $200 \mathrm{mg} /$ tablet & $198.8 \mathrm{mg} / \mathrm{tablet}$ & $99.4 \pm 12$ & $\mathbf{1 . 1 3}$ \\
\hline
\end{tabular}

* Average of six determinations, SD denotes standard deviation; RSD denotes \% relative standard deviation.

\section{RESULTS AND DISCUSSION}

Since the above-mentioned PAZO is polar, and RP-HPLC method was used. The column for the separation was a $\mathrm{C}_{18}$ column that has an internal diameter of $4.5 \mathrm{~mm}$, length of $150 \mathrm{~mm}$, and $3.5 \mu \mathrm{m}$ particle size. Multiple numbers of trials were performed using various buffer solutions with various compositions of methanol, ethanol, acetonitrile, and HPLC grade water and variable flow rates. Eventually, optimum separation was obtained with a mixture of $0.1 \%$ Orthophosphoric acid: Acetonitrile (55:45 \% v/v). The mobile phase flow rate was adjusted at $1 \mathrm{~mL} / \mathrm{min}$, and the detection wavelength was set at $271.4 \mathrm{~nm}$. Thus, a proper chromatographic peak was obtained with excellent symmetry and the least peak tailing. The chromatograms of various concentrations were shown in Fig. 3 - Fig. 3d.

System suitability was accompanied as per the methodology system suitability solution, and six replicate of standard preparation was injected into HPLC. The tailing factor was found to be 1.122 . The number of theoretical plates was 3863; the number of theoretical plates per meter was 77,360. The retention time was found out to be 1.430 minutes, and the $\%$ RSD was calculated to 0.112 . The results were well within the acceptance criteria, and the study concludes the suitability of the analytical system for analysis.

The precision of the method was examined by using System precision, Method, and Intermediate precisions. Various levels of concentration were taken in six replicate samples. For Method and Intermediate precisions, the \%RSD was found to be 0.54087 and 0.60606 . The \% RSD of the System precision was found to be 0.01168 . The precision at different levels was mentioned in Table $3 \mathrm{~b}$. The results are well within the acceptance criteria, and the \% RSD observed for the replicate injections indicates the precision of the HPLC used, assay values indicate the precision of the method.

The linearity of PAZO was determined in the concentration range of $2 \mu \mathrm{g} / \mathrm{mL}$ to $10 \mu \mathrm{g} / \mathrm{mL}$ of the test concentration. The squared correlation coefficient value was found to be 0.999 , which is well within the limit. The results of the linearity studies were mentioned in Table $2 c$.

To determine the accuracy of the PAZO, the drug was spiked with a placebo at three different levels in triplicate preparations. The results of accuracy are mentioned in the Table, and the results of precision at accuracy are given in the Table. The mean \% recovery at each level was found out to be within limits i.e., $98.0 \%$ to $102.0 \%$

The robustness of the HPLC was determined for the suitability and assay value under multiple variable conditions like Flow rate change, Wavelength change, and change in mobile phase composition. The results are mentioned in Table 3.

The Limit of Detection and Limit of Quantitation of PAZO were found out to be $0.1675 \mu \mathrm{g} / \mathrm{mL}$ and $0.0552 \mu \mathrm{g} / \mathrm{mL}$, respectively, which is represented by Table $3 a$.

The $\%$ assay of the PAZO was found to be $99.4 \pm 1.2$, (Table 4) which was in good agreement with the labeled claim. The method was specific and has no interference observed when the PAZO was determined in presence of excipients.

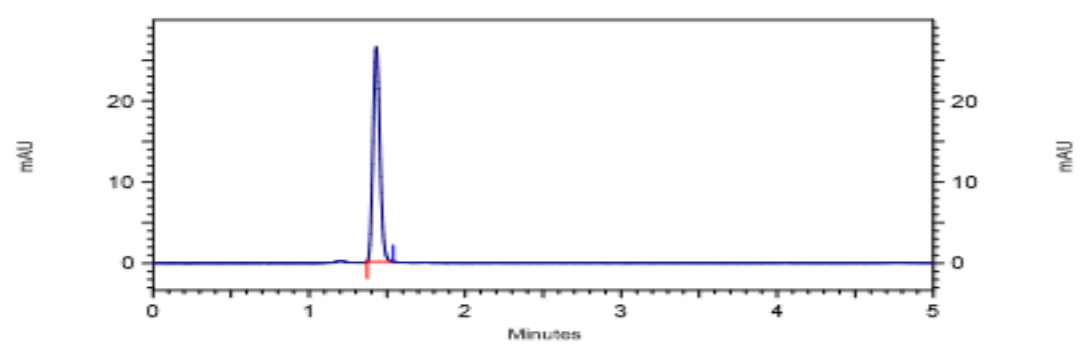

VWD: Signal A,
271 nm Results
Retention

Retention Tim

Area Theoretical
plates (USP)

Asymmetry

Totals

1364103

Figure 3: Standard chromatogram of Pazopanib Hydrochloride $(2 \mu \mathrm{g} / \mathrm{mL})$ 


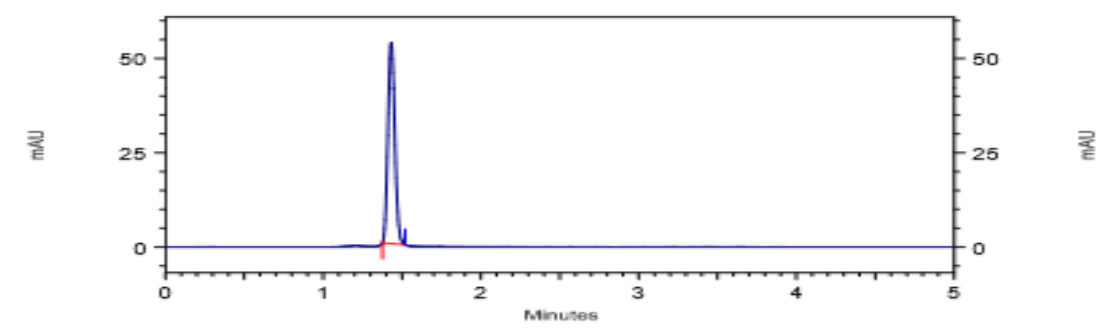

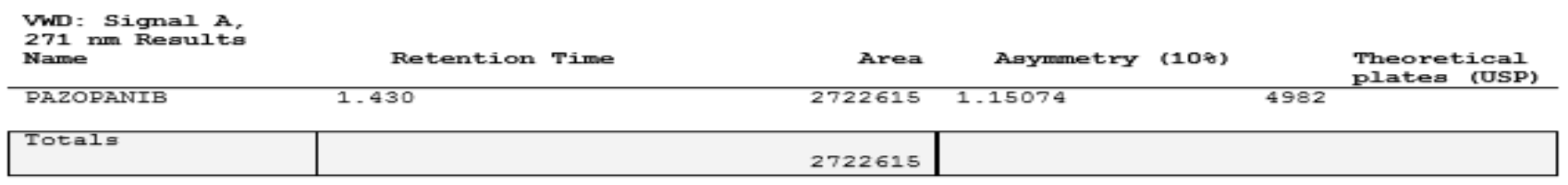

Figure 3a: Standard chromatogram of Pazopanib Hydrochloride $(4 \mu \mathrm{g} / \mathrm{mL})$

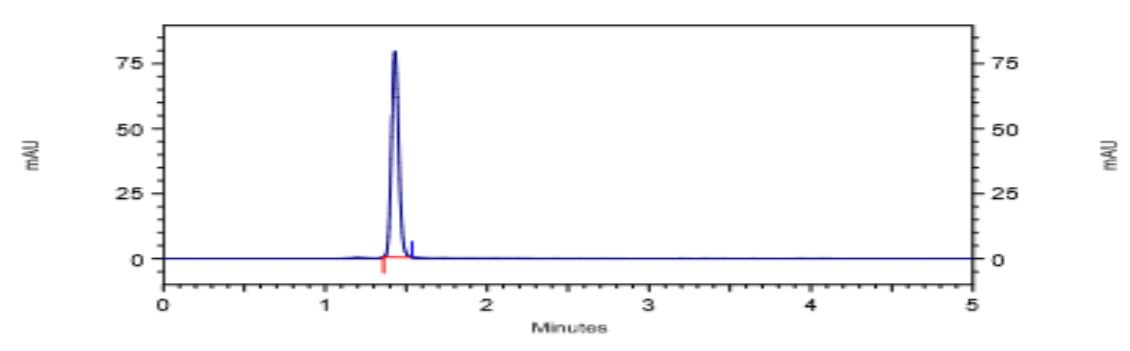

\begin{tabular}{|c|c|c|c|c|}
\hline Name & Retention Time & Area & Asymetry & $\begin{array}{l}\text { Theoretical } \\
\text { plates (USP) }\end{array}$ \\
\hline PAZOPANIB & 1.430 & 4096869 & 1.11325 & \\
\hline Totals & & 4096869 & & \\
\hline
\end{tabular}

Figure 3b: Standard chromatogram of Pazopanib Hydrochloride (6 $\mu \mathrm{g} / \mathrm{mL}$ )
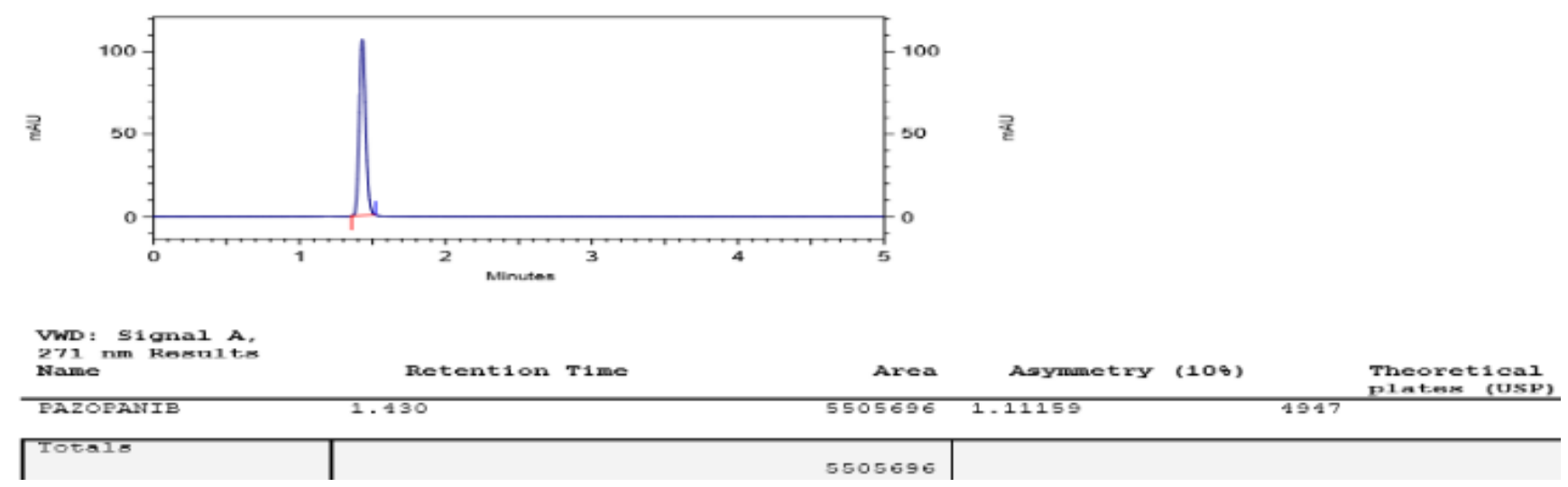

Figure 3c: Standard chromatogram of Pazopanib Hydrochloride $(8 \mu \mathrm{g} / \mathrm{mL})$

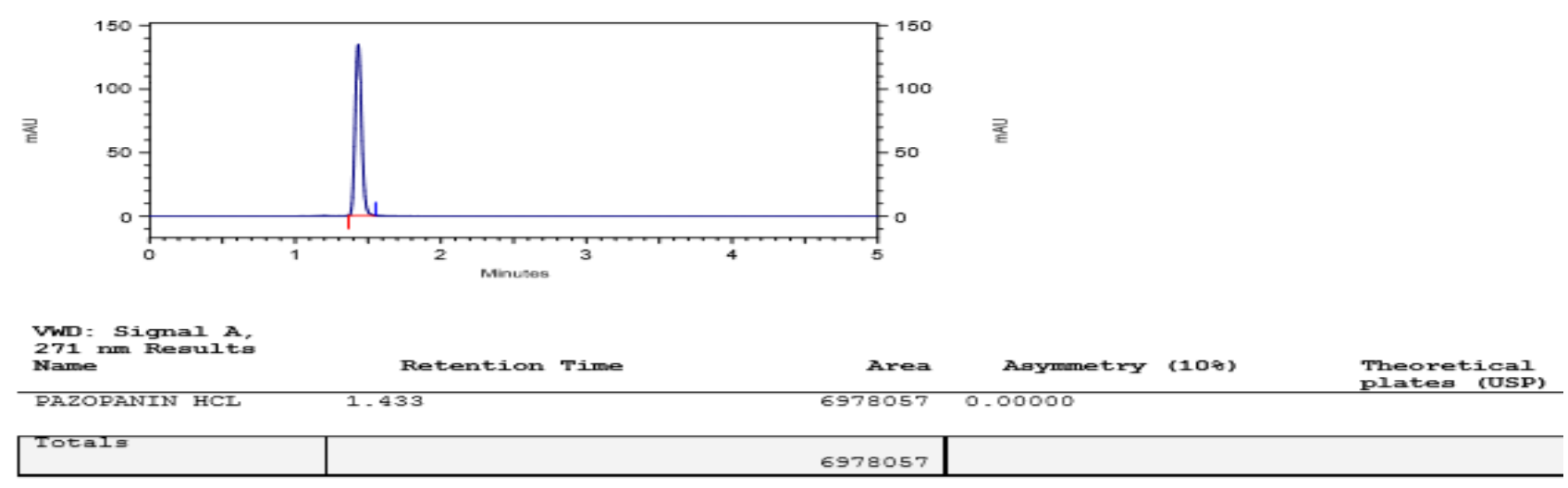

Figure 3d: Standard chromatogram of Pazopanib Hydrochloride (10 $\mu \mathrm{g} / \mathrm{mL})$ 


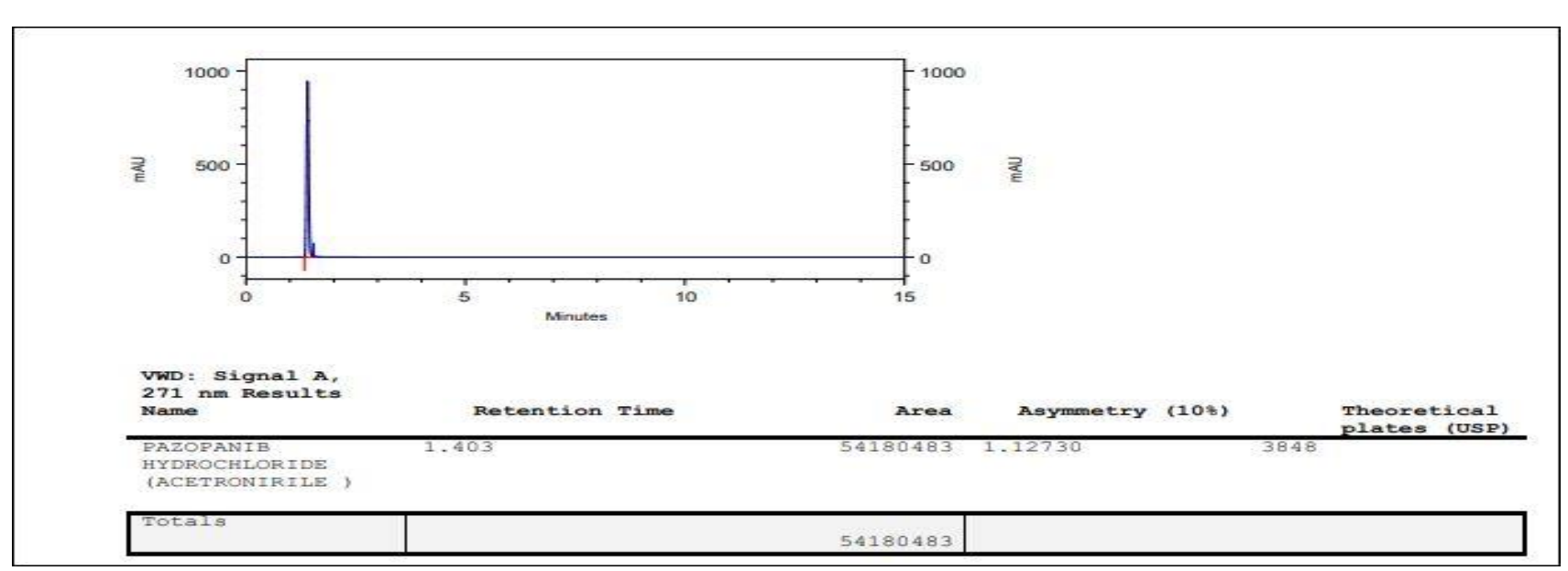

Figure 4: Sample chromatogram of Pazopanib Hydrochloride (Votrient)

\section{CONCLUSION}

The existent study demonstrated a validated Reverse Phase High-Performance Liquid Chromatography (RPHPLC) method for the estimation of PAZO available as the tablet dosage form. The scope of the present work is to build up the linearity and optimization of the chromatographic conditions, to develop the RP-HPLC method for the determination of drugs in the tablet dosage form. The method was wholly validated and showed satisfactory results. The method was free from the interference of the other active ingredients and additives used in the formulation. The RP-HPLC method for the estimation of PAZO has various advantages like less solvent consumption, low retention time, good peak symmetry, precision, accuracy, and robustness. The results of the study indicate that the developed method was found to be accurate, precise, linear, sensitive, simple, economical, and reproducible, which has a short run time, which makes the method rapid. Hence it can be concluded that this method may be employed for the routine quality control analysis of PAZO in active pharmaceutical preparations.

Acknowledgement: The authors are thankful to Hetero Labs for providing the sample of PAZO. We are very grateful to Dr. L. Rathaiah, esteemed chairman of Vignan group of institutions, Vadlamudi, Guntur, for providing us the essential laboratory facilities to carry out the current investigation.

\section{REFERENCES}

1. Remy B Verheijen, BasThijssen, Hilde Rosing, Jan H M Schellens, Lianda Nan, Nikkie Venekamp, Jos $\mathrm{H}$ Beijnen, Neeltje Steeghs, Alwin D R Huitema, Fast and Straight forward method for the quantification of Pazopanib in human plasma using LC-MS/MS, Therapeutic Drug Monitoring, 2018;40(2):230-236. doi: 10.1097/FTD.0000000000000479.

2. Remy B Verheijen, Sander Bins, Development and clinical validation of an LC-MS/MS method for the quantification of Pazopanib in DBS. bioanalysis, 2016;8(2):123-34.
3. Mukul Minocha, Varun Khurana, Determination of Pazopanib (GW-786034) in Mouse Plasma and Brain Tissue by Liquid Chromatography-Tandem Mass Spectrometry (LC/MS-MS), J Chromatogr B Analyst Technol Biomed Life Sci. 2012;90:85-92.

4. Rolf W Sparidans, Tahani T A Ahmed, Liquid Chromatography-Tandem Mass Spectrometric Assay for Therapeutic Drug Monitoring of the Tyrosine Kinase inhibitor Pazopanib in Human Plasma. J Chromatogr B Analyst Technol Biomed LIFE Sci, 2012;905:137-40.

5. Claire Pressiat, Huu-Hien Huynh, Alain Ple, Development and Validation of a Simultaneous Quantification Method of Ruxolitinib, Vismodegib, Olaparib, and Pazopanib in Human Plasma Using Liquid Chromatography Coupled With Tandem Mass Spectrometry, The Drug Monit. Journal, 2018;40(3):337-343.

6. Prinesh N Patel, Pradipbhai D Kalariya, Characterization of Forced Degradation Products of Pazopanib Hydrochloride by UHPLCQ-TOF/MS and in Silico Toxicity Prediction. Journal of Mass Spectrometry, 2015;50(7):918-28.

7. Vanesa Escudero-Ortiz, Development and Validation of an HPLC-UV Method for Pazopanib Quantification in Human Plasma and application to Patients with Cancer in Routine Clinical Practice, Therapeutic Drug Monitoring.2015;37(2):172-9.

8. Musty Sharada, Ravichandra Babu R, Determination and characterization of process impurities in Pazopanib hydrochloride drug Substance, International Journal of Pharmacy and Pharmaceutical Sciences, 2016;8:0975-1491.

9. Ravi Sankar P, Saisneha Latha K, Bhavani Sailu A, Taheera SK, Madhuri B, Development and Validation of RP-HPLC Method for the Determination of Pazopanib Hydrochloride (A Tyrosine Kinase Inhibitor) in Pharmaceutical Dosage Form, Research J. Pharm. and Tech 2021;14(3):1549-1554. 
10. Chaitanya G, Prasanna Kumar K, Harini U, Lingam M, and K. M. Pawar A, Development and validation of rapid RP HPLC-PDA method for the analysis of Pazopanib hydrochloride in bulk, dosage forms and in in vitro dissolution samples, India Journal of Chemical and Pharmaceutical Research, 2015;7(12):950-960.

11. Ravisankar P, D Rao G, N Kumar M, Chaitanya MK, An improved RP-HPLC method for the quantitative determination of capecitabine in bulk and pharmaceutical tablet dosage form, Journal of Chemical and Pharmaceutical Research, 2013;5(3):249-260.

12. Chaitanya G and Pawar AKM, Development and Validation of UV spectrophotometric method for the determination of Pazopanib hydrochloride in bulk and tablet formulation, Journal of Chemical and Pharmaceutical Research, 2015;7(12):219-225.

13. Saisneha Latha $K$, Ravisankar $P$, Srinivasa Babu $P$, Development and validation of UV spectrophotometric method for the determination of Pazopanib hydrochloride in pharmaceutical dosage form, Int. J.Pharm. Sci.Rev, Res., 2020;61(2):13-18.

14. Ravi Sankar P, Sai Snehalatha K, Tabassum Firdose Shaik, Srinivasa Babu P, Applications of HPLC in Pharmaceutical Analysis, Int.J.Pharm.Sci.Rev.Res. 2019;59(1):117-124.
15. Bokai Ma, XinLei Gou, Application of highperformance liquid chromatography in food and drug safety analysis, Journal of food safety and quality, 2016;7:295-4298.

16. Ravi Sankar P, Rajyalakshmi G, Devadasu Ch, Devala Rao G, Instant tips for a right and effective approach to solve HPLC troubleshooting, Journal of Chemical and Pharmaceutical Sciences, 2014;7(3):191-206.

17. Ravisankar $P$, Naga Navya Ch, Pravallika D, Navya Sri $D, A$ review on step-by-step analytical method validation, IOSR Journal of Pharmacy, 2015;5:7-19.

18. Ravisankar P, Gowthami S, Devala Rao G, A review on analytical method development, Indian journal of research in pharmacy and Biotechnology, 2014;2:1183-1195.

19. Ravisankar Panchumarthy, Anusha S, Supriya K, Ajith Kumar U, Fundamental chromatographic parameters, Int. J. Pharm. Sci. Rev, Res. 2019;55(2):46-50. Ravisankar P, Sai Geethika A, Racgana G, Srinivasa Babu P, Bhargavi J, Bioanalytical method validation: A comprehensive review, Int.J. Pharm. Sci. Rev. Res, 2019;56(1),50-58.

20. ICH Q2 (R1), Validation of analytical procedures, Text, and methodology, International Conference on Harmonization, Geneva, 2005,1-17.

Source of Support: None declared.

Conflict of Interest: None declared.

For any question relates to this article, please reach us at: editor@globalresearchonline.net New manuscripts for publication can be submitted at: submit@globalresearchonline.net and submit_ijpsrr@rediffmail.com 